\title{
ASSESSING AND MITIGATING STUDIES OF THE ENVIRONMENTAL AND ECOLOGICAL IMPACTS OF 2011 WINTER UNIVERSIADE IN ERZURUM, TURKEY
}

\author{
Zeynep Eren* \\ Ataturk University, Environmental Engineering Department, 25240 Erzurum Turkey; \\ *Corresponding Author: Zeynep EREN, e-mail: zeren@atauni.edu.tr;
}

Received February, 2018; Accepted March, 2018; Published May, 2018;

doi: https://doi.org/10.31407/ijees838

UOI license: http://u-o-i.org/1.01/ijees/14944105

\begin{abstract}
Nowadays, the environmental and ecological impacts of international sporting events have received increasing attention despite its difficult assessment. These events have potential impact on local eco-systems by contributing greenhouse gas emissions related to climate change and utilizing more water and natural sources causing the water and soil pollution due to significant re-development of host city. Therefore, environmental management systems are required for mega sports events in terms of their contribution to air, water and soil pollution. This paper examines three such implementation processes that the mitigation for the greenhouse gases caused by newly constructed and renovated of existing buildings and transportation improvements caused by the contribution of new motor vehicles to city center and recycling the wastes for the environmental management of Erzurum 2011 Winter Universiade preand during games. Therefore, the aim of this study is to calculate the carbon dioxide emission related to climate change from re-insulated buildings designed for accommodation in Athletes Village, to reduce the transportationbased air pollution with emission controlling all motor vehicles newly joined in city traffic and to disseminate the waste recycling originated from sports venues with the recycling equipment during the games. It is achieved a $68.4 \%$ carbon reduction of total carbon dioxide emission with the insulation of re-constructed accommodation buildings while it is accomplished nearly $75 \%$ waste recycling of total wastes generated during 25th World Universities Winter Games which was hosted in Erzurum in 2011.
\end{abstract}

Keywords: Environmental management, sports events, recycling, greenhouse gas. 